\title{
The Biology of Obsessive-Compulsive Personality Disorder Symptomatology: Identifying an Extremely $K$-Selected Life History Variant
}

\author{
Steven C. Hertler ${ }^{1,2}$
}

Published online: 10 September 2015

(C) Springer International Publishing 2015

\begin{abstract}
Size at birth, growth rate, age at sexual maturity, number and size of offspring, and longevity are among the variables studied in life history evolution, a mid-level branch of evolutionary biology. Long-lived, slow maturing, and highly encephalized Homo sapiens, though skewed as a group towards the very slow end of the spectrum, nevertheless show some life history variation; variation which may relate to, and to some extent explain, personality variation. When applied to extant personality disorders, the risk-taking, boldness, and impulsivity of psychopathy is explained as a fast life history strategy. Herein, it is argued that the highly heritable obsessive-compulsive personality disorder (OCPD), opposite psychopathy, is a slow life history strategy. Both OCPD and slow life history strategists exhibit anxiety and harm avoidance, risk and loss aversion, future-oriented thought and time urgency, delayed gratification, and conscientious labor and fidelity. In addition to a host of compelling correlations, the preponderance of intrinsic over extrinsic mortality that explains the evolution of slow life histories is precisely that which has been described in an ecological etiology that explains OCPD as a product of post-migration evolution from Africa into Eurasia.
\end{abstract}

Keywords Obsessive-compulsive personality disorder . Anankastic $\cdot$ Life history $\cdot$ Evolution $\cdot$ Mortality $\cdot$ Extrinsic . Intrinsic $\cdot$ Conscientiousness

Steven C. Hertler

psychodiagnostics@hotmail.com; stevenhertler@hotmail.com

1 College of New Rochelle, New Rochelle, NY 10801, USA

2115 Pine Street, Ridgewood, NJ 07450, USA

\section{Introduction}

With highly precocial young born every 90 days, approximately 100 elephant shrew generations can mature, breed, and die (Skinner and Chimimba 2005) during just one 17.4year elephant generation (Okello et al. 2008; Moss et al. 2011). Understanding why these mammals, and other animals, complete their life cycles across vastly different time scales is the province of life history evolution, a line of study that emerged over the last 50 years at the interface between biology, ecology, zoology, botany, ornithology, and genetics (Lack 1966; MacArthur and Wilson 1967; Stearns 1992; Charnov 1993). In a word, life history is the unfixed journey between egg and corpse (Flatt and Heyland 2011), conception and death, germination and decomposition. Being a sort of developmental biography of organisms (Schechter and Francis 2010), life history evolution measures the variability in the tradeoffs between somatic investment and reproductive investment that takes place between the start and end of life (Braendle et al. 2011); tradeoffs which are made across the following classical life history variables or variable clusters: (1) size at birth, (2) growth pattern, (3) age and size at maturity, (4) number, size, and sex ratio of offspring, (5) age- and size-specific reproductive investments, (6) age- and sizespecific mortality schedules, (7) length of life (Stearns 1992; Braendle et al. 2011). As might be suspected, these seven life history variables are intercorrelated, such that size at birth predicts length of life, age of maturity predicts age of mortality, and so forth. To these classical biometric life history variables have been added sociometric traits including altruistic collaboration (Figueredo et al. 2011), and psychometric traits including general intelligence (Rushton 2004). Evolution then often operates on life history traits as if they were a complex. For instance, growth trajectory, reproductive timing, senescence, and mortality (Morris 2009) ineluctably form an 
interdependent complex because it is not possible for an organism to grow quickly, reproduce exponentially, and live perpetually. Energy is a finite resource. In consequence, optimums cannot be concurrently pursued (Belsky et al. 2012), by, for example, simultaneously maximizing perpetuation and propagation.

\section{The Slow Life Histories of Humans}

The speed of life history is distributed along a continuum, anchored by the fast or $r$ selected on one side, and the slow or $K$-selected on the other. ${ }^{1}$ Inclusive even of diminutive species like the mouse lemur that are certainly $r$ strategists among the order (Wilson 1975/2000), primates are generally much closer to the $K$-selected elephant than to the $r$-selected elephant shrew. Among primates, gestation, birth weight, weaning age, and sexual maturity can respectively range up to 250 days, $2000 \mathrm{~g}, 1500$ days, and 9 years, while its lower bound estimates remain minimally 60 days, $10 \mathrm{~g}, 50$ days, and nearly 1 year (Harvey and Clutton-Brock 1985). Across the order of primates, and even within the superfamily Hominoidea, humans show a species-specific set of life history characteristics, which are exceptional for slowness ${ }^{2}$; as such, humans, the longest lived terrestrial mammal (Ellis et al. 2009), are said to be moderately (MacDonald 1997) to extremely (Ellis 1987; 1988; Figueredo et al. 2007) $K$-selected. What is more, humans are not only slow to develop (Kaplan et al. 2000), mature, and senesce (Muehlenbein and Flinn 2011), but also exhibit the slow life history traits of neoteny (Godfrey and Sutherland 1996; Bufill et al. 2011; Petanjek et al. 2011), alloparental and biparental care (Meehan 2005; Quinlan and Quinlan 2008), late age at first reproduction (Campbell 1972), singleton births in most instances (Hall 2003), multigenerational kin-networks (Bengtson 2001), and high enculturation (Bering 2004).

\section{Intraspecific Variation Across Life History Parameters}

Across the seven variables outlined by Stearns (1992), life histories vary as a function of phylogenetic relatedness

\footnotetext{
${ }^{1}$ The $r$ used above refers to rate, which, along with $K$ for carrying capacity, was part of the shorthand notations used by the innovators of life history theory, MacArthur and Wilson. Though the density dependence that these notations were used to calculate has been superseded by direct measures of mortality, their use above follows the modern convention of using $r$ and $K$ as shorthand references to fast and slow life histories respectively.

${ }^{2}$ Though humans are more $K$ selected than are other apes on almost all life history characteristics, they do show an earlier weaning age and shorter inter-birth interval $(<<<$ Ellis, Figueredo, Brumbach, \& Schlomer, 2009). It is very likely the extended kinship arrangements and social living allow this particular aspect of life history to stand out as less extremely $K$-selected.
}

(time since common ancestor). This is to say that, with some qualification (Stearns 1983) and to varying degrees (Kamilar and Cooper 2013), life history traits will be more similar among species within a genus, genera within a family, and families within an order. Though not specifically supported by phylogenetic life history studies, it follows that intraspecific variation (variation within a species) is least pronounced. Nevertheless, as reviewed by Figueredo et al. (2005), there is still some intraspecific variation across life history traits, evidenced by studies of dandelions, field mice, American shad, flies, and milkweed bugs. Homo sapiens are not excepted (Weizmann et al. 1990; Sherman et al. 2013; Gladden et al. 2008; Rushton 1985; 2000; Walker and Hamilton 2008). The study of instraspecific variation in human life history traits became known as Differential $K$ Theory (Figueredo et al. 2005; Rushton 1985; 1987; 1990; 1995; 2004), and was first applied to understand racial variation between groups, but is now being applied to understanding behavioral, attitudinal, cognitive, and health-related variation within groups (Figueredo et al. 2005). This variation is (1) detected within massive datasets derived from the Terman Life-Cycle Study (McCann 2005) and the Midlife in the United States (MIDUS) survey (Figueredo et al. 2005); (2) gleaned via responses on the Life Experiences Questionnaire, the Self-Control Schedule, and The Barrett Impulsivity Scale (Figueredo et al. 2006); (3) inferred from mating inventories such as the Mating Effort Scale and the Mate Value Inventory (Figueredo et al. 2011); (4) quantified directly via the Arizona Life History Battery (Gladden et al. 2009) and its shortened form, the Mini-K (Figueredo et al. 2006); and (5) aggregated into several organizing variables such as the $K$ Factor (Rushton 1985), the General Factor of Personality (Rushton et al. 2008), the Genetic K Factor (Figueredo et al. 2006), and Covitality (Figueredo et al. 2004).

Through the efforts just described, life history has been established as a heritable, temporally stable, and reliably detectable (Figueredo et al. 2014a) constellation of biomarkers meaningfully associated with several personality variables, among which are conscientiousness (McCann 2005), impulsivity (Figueredo et al. 2006), and risktaking (Brumbach et al. 2009). On the other hand, life history theory, for all the above-described success in explaining personality traits, has less commonly explained personality patterns, such as the ten personality disorders described in the American Psychiatric Association's Diagnostic and Statistical Manual of Mental Disorders (DSM) (2013). Psychopathy is an established exception illustrative of the fast life history. As will be seen, comparisons with psychopathy suggest Obsessive-Compulsive Personality Disorder (OCPD) may be illustrative of the slow life history. 


\section{Personality Patterns and Life History Evolution}

Conceptually overlapping with antisocial personality disorder and sociopathy (Mealey 1995), psychopathy is a highly heritable neurocognitive pattern (Blair et al. 2005) eliciting exploitative, manipulative (Hare et al. 1989), sensation seeking (Portnoy et al. 2014), and Machiavellian (Paulhus and Williams 2002) behavior. Historically envisioned as a product of habitual abuse and poor attachment, there is, however, scant support for the causality of these environmental insults (Blair et al. 2005). If one were to dichotomize, it now appears that psychopathic brains cause poor attachment, rather than the reverse (Blair et al. 2005). Even before psychopathy was firmly established as organic, heritable, and reproductively competitive (Gutiérrez et al. 2013), biological theories steadily accrued through the 1980s (Kenrick et al. 1983; MacMillan and Kofoed 1984; Kofoed and MacMillan 1986; Harpending and Sobus 1987; Cohen and Machalek 1988) and continued apace ever since (Wilson et al. 1996; Seto, et al. 1997; Colman and Wilson 1997; Quinsey 2002; Mokros et al. 2008; Walsh and Wu 2008; Brune 2008; Krupp et al. 2012). Most recently, the psychopathic complex was recognized as an extreme life history variant, functioning at the fast end of the spectrum (Jonason and Tost 2010; McDonald et al. 2012; Jonason et al. 2012; Jones and Figueredo 2013; Wenner et al. 2013), as evidenced by the pursuit of short-term matings, as well as of reduced empathy, altruism, and impulse control (Jonason et al. 2010). Psychopathy, it has been concluded, maps well onto the multiple dimensions of a fast life history strategy (Jonason and Webster 2010).

Psychopathy ${ }^{3}$ has been described as diametrically opposite Obsessive-Compulsive Personality Disorder (Hertler 2014a), hereafter often referred to as obsessive character, or simply obsessive. Diagnosable as one of three anxious and fearful personality disorders (American Psychiatric Association 2000; 2013), OCPD is a behavioral complex consisting of a core of excessive conscientiousness (Samuel and Widiger 2011) in which leisure is fully subordinated to labor (American Psychiatric Association 2000). Added to this core of conscientiousness, obsessives are closed to experiencing new ideas (Warner et al. 2004), anxious and fearful (Sperry 2003), over-controlled (Shapiro 1999), guarded, contrary (Widiger and Costa 1994), rigid (American Psychiatric Association 2000; 2013), risk averse (Chapman et al. 2007), harm avoidant (Spinhoven et al. 2009), and parsimonious (Freud 1908/1959). The extreme dissimilarities between the psychopathic and obsessive patterns emerge across the 20

\footnotetext{
${ }_{3}^{3}$ Precisely, it was Antisocial Personality Disorder that was described in Hertler (2014a), which is the name of an impulsive, erratic Cluster B personality disorder (American Psychiatric Association 2000) understood by many as synonymous with psychopathy or sociopathy. For those seeking disambiguating literature, see Mealey (1995)
}

items of the Hare Psychopathy Checklist (PCL-R), the preeminent self-report measure operationalizing psychopathy (Hertler 2014a). For instance, PCL-R items 10 and 14, denoting disinhibition, contrast strongly with obsessive rigidity, as noted by the American Psychiatric Association (2013) and markers of behavioral overcontrol riddling the literature (Millon and Davis 1996; Shapiro 1999; Salzman 1985). Similarly, these personality patterns are temporally separated, with psychopaths showing a lack of realistic longer-term goals and general irresponsibility, as respectively coded by PCL-R items 13 and 15. Alternatively, obsessives are widely understood to subordinate the present to the future (Campos 1966; Pettit 1969; Pollak 1979; Salzman 1985; Gibbs Gallagher et al. 2003; Eskedal and Demitri 2006). Also, while psychopaths are sensation seeking, as coded by PCL-R item 3, obsessives are anxious and fearful (American Psychiatric Association 2013) and explicitly show low sensation seeking within trait studies (Lynam and Widiger 2001). Finally, of note, the parasitic lifestyle coded by PCL-R item 9, which is so definitional of the psychopathic, is the converse of the disproportionate devotion to work, described in OCPD criterion three, and written so extensively about in the associated features section of the DSM.

In this way, on the PCL-R, as well as with respect to goal attainment, conscientiousness, risk-taking, temperament, inferred frontal lobe function, and etiology, the obsessive and psychopathic were previously contrasted (Hertler 2014a), after which, at the end of the discussion section, it was suggested that these patterns were indeed contrasting life history strategies (Hertler 2014a). A mere 4 months later, Del Giudice (2014), working independently on developing a pioneering framework for organizing psychopathology along a life history continuum, discussed OCPD as one of several disorders illustrative of slow spectrum life history. Nevertheless, the first paper does not take life history evolution as its focus, and the second paper does not take OCPD as its focus; accordingly, OCPD's status as a slow life history variant remains only briefly discussed.

\section{Purpose and Structure}

The purpose of the present paper is to corroborate the abovedescribed thesis advanced separately by Hertler (2014a) and Del Giudice (2014). This paper jointly surveys the personality literature and life history literature in order to show ObsessiveCompulsive Personality Disorder to be an extremely $K$-selected variant. This aim is pursued by reviewing the following classes of characteristics that are descriptive of obsessives and indicative of a slow life history: Anxiety and harm avoidance (section 3), risk aversion and loss aversion (section 3.1), future-oriented thought (section 3.2), executive control (section 3.3), compulsivity and conventionality (section 3.4), 
conscientiousness (section 3.5), capital and embodied capital (section 3.6), and fidelity and parental effort (section 3.7). Subsequently, etiology (section 4), future research (section 4.1), limitations (section 4.2), and diagnostic implications (section 4.3) are discussed.

\section{Life History of OCPD: Anxiety and Harm Avoidance}

The status of anxiety within the life history literature is somewhat mixed. Several studies using the Arizona Life History Battery and the Mini-K have found negative associations between anxiety and life history speed, or some component thereof (Kirsner et al. 2009; Figueredo et al. 2013; Manson 2015). Other researchers (Figueredo et al. 2014b) contend, and are now attempting to empirically demonstrate, that anxious ideation marks the slow life history, while affective anxiety marks the fast life history. Still, slow life histories have been associated with physical signs of tension and anxiety, and also insecurity, fearful and timid behaviors, need to seek reassurance, and over-controlling personalities (Sherman et al. 2013; Rushton et al. 2009). Additionally, as reviewed by Dunkel et al. (2014) anxiety is elevated among those groups described as having slower life histories. For instance, women, longer-lived and generally assumed to express slower life histories (Geary 2003), show elevations on performancebased tests of anxiety (Egloff and Schmukle 2004) and are more commonly assigned anxiety disorder diagnoses (Lewinsohn et al. 1998; Vesga-López et al. 2008). Racial analysis shows similar support. East Asians have comparatively high anxiety and slow life histories (Rushton 2000; Dunkel et al. 2014). Alternatively, those of African Ancestry show group means that are both low in anxiety (Himle et al. 2009; Woodward et al. 2012) and fast in life history (Dunkel et al. 2014).

Following this connection between life history and anxious harm avoidance, it is then relevant to note that, unlike the hypoaroused nervous system of the psychopath (Harpending and Sobus 1987) with its reduced startle reaction, muted galvanic skin response, and subdued experiential anxiety (Hertler 2014a; Millon and Davis 1996), the obsessive expresses persistent anxious tension (Millon and Davis 1996), consistent with its classification as an anxious and fearful personality disorder (American Psychiatric Association 2000; 2013). Obsessive character is associated with anxious harm avoidance across disciplines as varied as psychoanalysis and genetics. Anxiety's status as a core temperamental feature of obsessive character is extant in the seminal writings of Freud (1908/ 1959), Pollak (1979; 1987), Shapiro (1999) and Salzman (1985). Through these writings, one can recognize a phenomenological state of heightened tension (Hertler 2015a), hyperfocus, hyperarousal, and future-oriented fear (Hertler 2015b). The writings of Mallinger (2009), representative of recent psychoanalytic theory, emphasize high anxiety, which the obsessive seeks to bring low by alertness, control and the pursuit of predictability and safety. The apprehensive ruminations (Mallinger 2009), fearful anticipations (American Psychiatric Association 2000), and worry induced actions (Pollak 1987) of the obsessive, may be best understood as systematic effortful information processing, which is phenomenologically similar to worry of the kind that is theoretically characteristic of slow life history strategists (Figueredo et al. 2014b). Additionally, like other anxious and fearful types, obsessive personality has been explicitly described as harm avoidant (Spinhoven et al. 2009). Added evidence of harm avoidance comes from recent genetics research (Hertler 2014a). Specifically, one Dopamine Receptor D3 (Glycine/ Glycine genotype) and two Dopamine Receptor D4 polymorphisms (the exon III variable number tandem repeat and the Cytosine/Cytosine genotype), thought indicative of avoidance and anxiety, have been associated with OCPD (Joyce et al. 2003).

\section{Risk Aversion and Loss Aversion}

As supported by animal models in which risk proneness was associated with fast life histories (Réale et al. 2000), impulsive risk-taking serves as an enduring behavioral correlate of the $r$ strategist (Figueredo et al. 2005; Møller and Garamszegi 2012). Alternatively, $K$ strategists will be temperamentally conservative risk takers (Wolf et al. 2007; Olderbak and Figueredo 2010; Olderbak et al. 2014) with behavioral decisions extending from that temperamental conservatism (van Schaik and Isler 2012). The $K$ strategist's expectation of a longer life and deeper time horizon, is predictably paired with conservative risk-taking (van Schaik and Isler 2012). Further illustrating the centrality of risk, psychometric estimation of the $K$ factor, an aggregate index of life history, included a revised version of the Risk Taking Behaviors scale, which inventories drinking, smoking, gambling, reckless driving, and risky sexual activity (Olderbak et al. 2014).

Psychopathy manifests a fast life history strategy partly due to the risk-taking it promotes (Gladden et al. 2009). In demonstration of the fact, psychopathy is related to 13 of 20 indexes of risk, such as self-reported drug and alcohol use, cigarette smoking, and number of sexual partners (Jonason et al. 2010). Abusing games of chance (Slutske et al. 2001) and showing comorbidity with pathological gambling (Wang 2006), psychopaths are more risk prone as measured by desisting later, and thereby assuming more risk, than controls on the Newman Card Playing Task (Blair and Frith 2000; Hertler 2014a). Alternatively, obsessive participants perform exactly opposite psychopaths when similarly observed in controlled gambling tasks (Hertler 2015b). Early on, Rosenwald (1972) showed experimentally that obsessives staked less money across gambling trials. Later, Chapman et al. (2007) 
described obsessives as exemplars of risk aversion after their study found them to eschew games of chance when possible, avoid high stakes, and respond extremely conservatively to risk on a structured gambling task (Hertler 2014a).

Without sufficient disambiguation, the terms risk-averse and loss-averse are liable to be thought synonymous; however, loss aversion actually denotes a specialized form of risktaking: strategic risk-taking to preserve holdings. The highly loss averse are then most subject to assuming risk, but only to avert loss (Figueredo et al. 2014b). Though research is limited, loss aversion, like risk aversion, is associated with slow life history strategists (Figueredo et al. 2014b). This connection between loss aversion and life history is thought to be mediated by resource accrual (Wolf et al. 2007), in that resources are preferentially accrued by $K$ strategists, who then express loss aversion to protect those resources (Figueredo et al. 2014b). Of note, obsessives fit both these criteria in that they are loss averse (Hertler 2014a) resource holders (Ullrich et al. 2007). As a consequence of habitually delaying gratification, preparing for the future, and laboring conscientiously, obsessives accrue more resources, which they then are naturally averse to losing.

\section{Future-Oriented Thought}

The slow life history strategy is premised upon the assumption of a long life. Consequently, future-oriented thought (Figueredo et al. 2006) is taken to be a $K$-selected trait (Griskevicius et al. 2011a, b). In contrast, those exposed to unpredictable environments and expressing a fast life history, discount future gains in preference to immediate rewards (Brumbach et al. 2009). Indeed, research indicates that $r$ strategists generally plan little for the future (Gladden et al. 2009; Figueredo et al. 2007), take risks (Figueredo et al. 2005), lack foresight (Figueredo et al. 2007), and disproportionately use alcohol, drugs, and cigarettes (Figueredo et al. 2006). Chisholm (1999a) relates life history evolution to time preference, recognizing apperceived time's ability to calibrate one's implicit discount rate, and, in turn, predict impulsivity, control, and delay of gratification. In choosing small immediate rewards, or forgoing them for larger future rewards, there is, in short, the expression of a behavioral algorithm used to mark the life history (Chisholm 1999a).

In contrast with the foreshortened future orientation of the psychopath, (Hertler 2014a; Petry 2002; Sher and Trull 1994), anticipations of the future dominate the obsessive's experience of the present (Salzman 1985; Hertler 2015b). In part, the conscientious and harm avoidant obsessive uses the present moment in preparation for the future exigency (Salzman 1985). And as previously reviewed (Hertler 2013), the obsessive's future orientation has been extensively documented in the work of Campos (1966), Pettit (1969), and Pollak (1979). Also as previously reviewed (Hertler 2013), Salzman, in a book entitled Treatment of the Obsessive Personality, includes a section on Time and the Obsessional, wherein time, for the obsessive, is described as an aversive stress to be conquered (Salzman 1985, p. 80). More recently, Eskedal and Demitri (2006) have noted that obsessives are conspicuously trained on the future. Additionally, empirical studies featuring obsessive samples yield performance-based elevations in preparatory activity, information seeking, and monitoring (Gibbs Gallagher et al. 2003), showing experimentally how the present moment is habitually subordinated to future exigencies (Hertler 2013). Time urgency, a corollary of future-oriented thought, is also felt as a matter of temperament; there is almost an instinctual sense that time is scarce and obligations are abundant (Hertler 2015c).

\section{Executive Control}

Wenner et al. (2013) suggest that cognitive aspects of life history are aptly captured by the term executive functioning. This relationship is borne out psychometrically. Frontal lobe control and executive functioning contributed to the development of the life-history-based General Factor of Personality (Rushton et al. 2008). Likewise, in developing the aforementioned $K$ Factor, Figueredo et al. (2006) used a measure of delinquent behavior described as the $D-20$, items from the Life Experiences Questionnaire relevant to risk-taking, as well as items from the Self-Control Schedule, the Self-Control Questionnaire, and the Barrett Impulsivity Scale. These instruments combined to form separate scales of impulsivity and self-control. The $K$ factor was then applied to a sample, showing that impulse control was an outgrowth of the slow life history. With impulsivity, or the relative absence of executive control, being so prominently insinuated into measures of life history, it is then not surprising that the established fast life history strategy of psychopathy, which has been cast as a disorder of executive dysfunction (Blair et al. 2005), shows aberrant frontal lobe function, reduced executive control, and behaviorally expressed impulsivity (Völlm, et al. 2004; Zeier et al. 2012; Schneidera et al. 2000). Rather than being capricious, rash, disinhibited, and impulsive, as is the psychopath, the obsessive is contemplative, over-controlled, overincorporative and compulsive (Hertler 2014a; Del Giudice 2014). With delay of gratification being associated with $K$ strategists (Griskevicius et al. 2011a), it is relevant to note that obsessives habitually delay gratification, as variously manifest as compulsivity, miserliness, and parsimony (Hertler 2014a). Additionally, just as the slow life history strategist postpones present pleasures in service of future ends (Figueredo and Rushton 2009), so does the obsessive (Shapiro 1999). Most recently, Pinto et al. (2014) experimentally confirmed these inferred relationships: As compared to a control group, obsessives less steeply discounted future rewards and more readily delayed gratification. 


\section{Compulsivity and Conventionality}

More than simply delaying gratification through executive control, slow life history strategists also adhere more willingly to cultural mores (Manson 2015) and societal regulations (Olderbak et al. 2014), such that they are given to staid conformity (Sherman et al. 2013). Here again, obsessive personality tracks with the slow life history literature. Whether referred to as behavioral inhibition (Gutiérrez et al. 2013), overcontrol (Steenkamp et al. 2015) or simply rigidity (American Psychiatric Association 2000; American Psychiatric Association 2013), obsessives exhibit rule bound behavior (Villemarette-Pittman et al. 2004) evident in the associated features section of the DSM, where it is noted that obsessives adhere to formulas, develop lists, and maintain schedules. Obsessives are likewise reverent of legitimate authority and habitually exhibit seriousness and reserve (American Psychiatric Association 2000). Labeling OCPD the conforming style, Millon and Davis (1996; page 518), cite restrained affectivity, interpersonal respectfulness, cognitive constriction, and behavioral rigidity, thereby capturing the full range of this controlling tendency as it is expressed across domains (1996; page 512). Consistent with other sources, these authors further note that obsessives adhere to ideals of propriety, convention and order, while following routinized and structured existence (Millon and Davis 1996).

\section{Conscientiousness}

Reminiscent of a temperamental counterpoint to executive functioning, conscientiousness imparts motivational stability, organization, and planning that encourages top-down control of behavior (DeYoung and Gray 2009). Conscientiousness does not only imply industriousness, but industriousness with some future end. Accordingly, it functions to subordinate present inclinations to future objectives (DeYoung and Gray 2009). Moreover, conscientious persons heavily weigh future outcomes, showing discounting rates with lower slopes that deviate from the hyperbolic discounting rates of those lacking this trait (Nettle and Clegg 2007). In some sense, futureoriented thought and time urgency are then an outgrowth of conscientiousness. In this way, conscientiousness connects to the above-referenced literature on future orientation, delay of gratification and decision making as it pertains both to life history and obsessive personality. Aside from this, there are direct connections between longevity, health and conscientiousness, evident prior to the application of the life history perspective to humans. For instance, beginning in 1921, and sampling more than 1500 persons longitudinally, the Terman Life-Cycle Study bore a conscientiousness-longevity relationship, equivalent to that of systolic blood pressure and cholesterol (Friedman et al. 1995; McCann 2005; Friedman et al. 1993). So then, most basically, the connection between health and longevity establishes conscientiousness as a life history marker. It does this by way of disposition to health behaviors (O'Connor et al. 2009) that are now understood as behavioral manifestations of somatic effort (Figueredo et al. 2006). Importantly, however, though conscientiousness promotes healthful behaviors, its associations with longevity are not exclusively explained by them after controlling for potential mediating variables (McCann 2005). In support of this position, conscientiousness has been related to more efficient viral suppression (Hackman and Hruschka 2013), while also being more pointedly and persistently associated with longevity within the context of life history studies (Brumbach et al. 2009). Conscientiousness now figures into the life historybased assessment conglomerates such as the general factor of personality (Rushton et al. 2008) and covitality (Figueredo et al. 2006). These myriad connections between conscientiousness and slow life history, whether they are behavioral in the case of exercise, or immunological in the case of viral suppression, are relevant in that they are markers of longevity-generating somatic effort. Somatic effort, the bioenergetic investment in bodily maintenance, contrasts with mating effort, the bio-energetic investment in offspring production. An increase of the former over the latter signifies a slowing of the life history (Figueredo et al. 2013), making the soma a correspondingly less disposable (Hill and Kaplan 1999; Hawkes 2003) vessel for its animating genes (Dawkins 1999; Dawkins 2006).

At the same time that conscientiousness is the most robust personality marker of slow life history, it is the defining personality trait of obsessive character. On factor analytic trait studies (Fossati et al. 2006), and within critical reviews (Hummelen et al. 2008), DSM criterion three (is excessively devoted to work) and criterion four (is over conscientious) are always included among the most efficient and powerful diagnostic markers of OCPD. Moreover, Samuel and Widiger (2010) find aspects of conscientiousness evident among most of the remaining six of the American Psychiatric Association (2000; 2013) diagnostic criteria, while Morey et al. (2003) understand conscientiousness to uniquely characterize OCPD (Hertler 2013). The reverse is also true. When parsing conscientiousness into its six facets, one finds obsessive personality related to them all (Hertler 2013). Thus, conscientiousness is understood as a hallmark of obsessive presentation (Hertler 2013; Deary et al. 1998; Morey et al. 2003; Samuel and Widiger 2010), leading trait theorists (Widiger et al. 2002; page 97) to describe OCPD as primarily a disorder of excessive Conscientiousness.

\section{Capital and Embodied Capital}

The accrual of capital is an emerging marker of the slow life history (Brumbach et al. 2009). Though increased income has been specifically associated with the slow life history (Kaplan 
and Bock 2001), capital accrual is used, not narrowly in exclusive reference to currency, but broadly in general reference to resources. Furthermore, in contrast to the accrual of tangible resources, embodied capital is understood as a culturally expressed form of somatic effort that marks the slow life history (Griskevicius et al. 2011b) of which knowledge acquisition (Griskevicius et al. 2011a, b) and skill development (Brumbach et al. 2009) are examples (Kaplan and Lancaster 2000).

There is some limited direct evidence relating obsessives to elevations in capital and embodied capital. For instance, home ownership is elevated among slow life history strategists (Brumbach et al. 2009), as it is among obsessives (Ullrich et al. 2007). Additionally, suggestive of knowledge and skill, obsessives attain high incomes, socioeconomic status, and managerial assignments (Ullrich et al. 2007). Also, obsessives, like others in the cluster $\mathrm{C}$ anxious and fearful category of personality disorders (American Psychiatric Association 2013), worked much, invested more in skill acquisition, and achieved higher vocational standards (Gutiérrez et al. 2013). This direct evidence is bolstered by obsessive traits which suggest the accrual of capital and investment in embodied capital: As per DSM criterion five, which denotes resource hoarding, and criterion seven, which records miserly spending (American Psychiatric Association 2000; 2013), and also consistent with Freud's original notation of parsimony as one of three defining characteristics (Freud 1908/1959), obsessives display what economist John Rae (1834; page 53) called the effective desire of accumulation (Frederick et al. 2002). Also, extreme elevations across all facets of conscientiousness, so high that they cannot be captured by traditional five-factor measures of personality (Haigler and Widiger 2001; Hertler 2014a), are also suggestive. This is because a meta-analytic study of conscientiousness indicated positive associations with education and job performance and thereby positive associations with income and rank (Ng and Feldman 2010).

\section{Fidelity and Parental Effort}

Life history is fundamentally a theory of differential resource allocation. As seen, vital energies can be invested in the soma in the form of somatic effort. Alternatively, energy not invested in the soma can be expended on reproduction, either in the form of parental investment or mating effort. Slow life histories are marked by somatic effort above reproductive effort, and thereafter, parental effort above mating effort (Figueredo et al. 2005; Olderbak et al. 2014). With a slower life history and less mating effort also come sexuality that is delayed and restrained (Figueredo et al. 2006), and investment in (Hackman and Hruschka 2013), and preference for pairbonding (Belsky et al. 2012) and monogamous mating (Figueredo et al. 2006).
As already seen, conscientiousness elevates somatic effort above reproductive effort, but conscientiousness may also elevate parental effort above mating effort. Conscientiousness, perhaps via its factors of responsibility, traditionalism, and virtue (Roberts et al. 2005; Hagger-Johnson and Whiteman 2007), is predictive of marital stability (Roberts et al. 2005; Kelly and Conley 1987; Shackelford and Buss 1997) and fidelity (Buss 2011). When all six of the above factors are considered, and when conscientiousness is properly perceived as a super-trait (Dumont 2010; Hertler 2014a), one can see how high conscientiousness imparts the capacity to acquire economic resources reliably over time and commit those resources to a mate and children (Buss 2011). In contrast, restricted conscientiousness is associated with short-term mating, impetuous promiscuity, infidelity, and unprotected sex (Nettle and Clegg 2007). The excess of conscientiousness among obsessives (Samuel and Widiger 2008; Widiger et al. 2002) imparts a laboring propensity via the first three factors, and a sense of contract and committal via the second three factors, which combine to create an engine of labor yoked to mate and progeny with the nepotistic effect of increasing fitness through kin selection. The compulsive conscientiousness imparted by the obsessive anxious temperament (Hertler 2015b), though it may not potentiate excesses of direct parental care, may well drive indirect parental care via increases in socioeconomic status, caloric intake, shelter, and aid. Alternatively, short-term mating, in which parental effort is subordinated to mating effort, is generally antithetical to the conscientiousness factors of responsibility, traditionalism, and virtue, and the obsessive's moral inflexibility and strict scrupulosity (American Psychiatric Association 2000). Also, with three fourths of obsessives being male (American Psychiatric Association 2000), it is pertinent to note that exceedingly conscientious men more readily secured long-term mating relationships (Nettle and Clegg 2007). Thus, elevated conscientiousness in the obsessive seems to promote, both the preference for, and ability to obtain, lasting long-term relationships.

\section{Discussion}

Opposite psychopathy, an established fast life history strategist, is obsessive personality, herein depicted as a slow life history strategist as demonstrated by several classes of correlates: anxiety, harm avoidance, risk aversion, loss aversion, future-oriented thought, executive control, compulsivity, conventionality, conscientiousness, capital accrual, fidelity, and parental effort. As has been shown, there is a suggestive connection within the empirical literature between these many variables and slow life history, and through them, between slow life history and obsessive-compulsive personality.

Beyond connecting correlates in this way, it is important to discuss etiology. A life history framework has etiological 
implications because, to claim that obsessive personality is an extreme life history variant, is to implicitly claim that obsessive personality has been evolved, and has an evolutionary history. Though traditionally explained psychoanalytically (Hertler 2014b), obsessive character was recently described as an evolved strategy (Hertler 2014a; 2015c). Specifically, obsessive character was hypothesized to be a product of post dispersal evolution out of Africa and into the temperate latitudes of Eurasia. This thesis explained obsessive cognition and behavior as arising from a two-part shift in the selective regime to which upper Paleolithic and early Neolithic migrants were exposed. As designated by the term ecological opportunity (Schluter 2000; Yoder et al. 2010), northward migration into Eurasia reduced biotic, density dependent selective pressures, including equatorial parasites (Bar-Yosef and Belfer-Cohen 2000, 2001; Phillips et al. 2010; Harcourt 2012) intraspecific competition (Cavalli-Sforza et al. 1994; Mellars 2006; Reich and Goldstein 1998) and conflict (Shea 2007). Second, as designated by the term migration load (Perin 2009), northward migration into Eurasia augmented abiotic, density-independent selective pressures, including cold and seasonal scarcity. Migration thus altered the selective regime, which then selected for obsessive psychology. With this two-part shift in the environmental selective regime, obsessive traits, such as extreme conscientiousness, reflexively future-oriented thought, and habitual parsimoniousness became at once practicable and adaptive; practicable because futurity was less uncertain, and adaptive because hardship was more certain (Hertler 2015c).

Beyond its simply being evolutionary, this etiology has several parallels with life history theory, as described by Rushton and later theorists. Both Rushton's research and this evolutionary etiology are fundamentally ecological in that they feature change in latitude as an important function of migration. As in this evolutionary etiology, Rushton emphasized the cold of higher latitudes as causal of evolutionary change. Furthermore, the evolutionary model in question (Hertler 2015c) is also consistent with more recent life history research, which situates stressors such as seasonal cold more explicitly within the context of mortality regime (Griskevicius et al. 2011a, b). Mortality regime is now commonly understood to calibrate the life history of the organism (Promislow and Harvey 1990; Franco and Silvertown 1997; Chisholm 1999a, b; Vindenes et al. 2012; McDonald et al. 2012; van Schaik and Isler 2012). As described by Sherman et al. (2013), unstable, uncontrollable, and unpredictable selective regimes impose high extrinsic mortality, shorten lifespans irrespective of the efforts of the organism, and thereby select for fast life histories. Alternatively, stable, controllable, and predictable selective regimes impose high intrinsic mortality, encouraging somatic investment, parental effort, and thereby select for slow life histories (Sherman et al. 2013; Ellis et al. 2009). So as intrinsic mortality waxes and extrinsic mortality wanes, life history slows. These are precisely the conditions specified as causal in the evolution of obsessive psychology: Northwarddispersing humans assumed a predictable, environmentally imposed hardship while being partially relieved of random, biotically imposed mortality (Hertler 2015c).

\section{Future Research}

In part then, because of associations between migration, latitude, and mortality regime, validating the present theory that obsessive character is a slow life history strategy, will come from obtaining support for the above-described evolutionary etiology. First, future research should reexamine latitude as it affects mortality regime and life history. Consistent with the hypothesized equatorial concentration of biotically imposed extrinsic mortality (Hertler 2015c), $99 \%$ of under-five childhood deaths are concentrated within India, Nigeria, Democratic Republic of the Congo, Pakistan, and China (Wertheim et al. 2012). The distribution of vectors, parasites and pathogens also show a strong latitudinal gradient (Wertheim et al. 2012; Low 1988). In addition to examining how latitude presently affects life history through mortality regime, the past must be considered. This line of research necessitates descending into the complexities of ancestral migration with its study of bottlenecks, drift, and founder effects, as well as of paleoclimate with its study of Milankovic Cycles, Heinrich Events, and oceanic oscillations. Such knowledge remains uncertain (Hetherington and Reid 2010); and moreover what is known is not yet sufficiently applied. Studying latitudinal effects on mortality regime will, of course, not only relate to obsessive etiology, but extends more broadly to the study of life history evolution. Second, and more specifically, as predicted by the ecological nature of this evolutionary theory, obsessives should be concentrated among ancestral inhabitants of higher latitudes. Obsessives should, for instance, be concentrated in those of European extraction as compared with those of Sub-Saharan African extraction (Hertler 2015c). Direct studies are limited. Nevertheless, there have been some comparisons of African-Americans to Caucasian Americans, which show no systematic differences in OCPD incidence (Chavira et al. 2003; Grant et al. 2012). However, significant genetic admixture (Bryc et al. 2015) partially undermines the utility of American samples. Studies more broadly focusing on the obsessive spectrum show mixed results, and anyway are of little applicability to OCPD per se (Matsunaga and Seedat 2007; Frost and Steketee 2002; Swets et al. 2014). On the other hand, the obsessive traits of time urgency and future-oriented thought, as well as parsimony and conservation of resources, appear to positively correlate with latitude (Hertler 2015c). Cross-national comparisons of self-reported conscientiousness correlates negatively with latitude, though, as reviewed, this data is open to several explanations, ranging from negation (Heine et al. 2008; van de Vijver and Leung 
2001; Cohen 2007) to inverse interpretation (Hertler 2015c). Clearly, more data is wanting. As detailed previously (Hertler 2015c), however, cross-national obsessive distribution may not be amenable to survey research, as per the ceiling effect (Haigler and Widiger 2001) and frame of reference effect (Schmit et al. 1995; Peng et al. 1997; Heine et al. 2002). Obsessive character might instead have to be measured using a combination of structured interview and demographic correlates of obsessive character such as SES, homeownership, time orientation, and several other variables previously outlined (Hertler 2015c).

Beyond corroborating an evolutionary account of obsessive etiology, future research must be directed towards explicitly locating $K$-selected traits within obsessive samples. Herein, evidence that obsessive character is an extremely $K$-selected variant has been culled indirectly from clinical research and psychoanalytic description. The former assumes obsessive character to be disordered while the latter finds parental harshness to be the source of that disorder. Under these assumptions, and without expressly holding a life history perspective, existing literature on obsessive character furnishes data largely relevant to sociometric and psychometric life history markers, which continue to be actively validated. The sociometric and psychometric markers herein reviewed should be confirmed within obsessive samples using the Arizona Life History Battery or analogous measures. More than this, future research should remedy the want of core biometric data. Longitudinal research should measure obsessive character's developmental pace, including growth rate, dental eruption, pubertal timing and age of naturally caused mortality. Slight slowing should be observed, consistent with the $K$-selected spectrum of developmental variance. Also, a life history perspective must compass mating, reproductive timing, and parental effort; all of which were logically neglected from a psychoanalytic perspective that scrutinized how obsessives were treated as children by their parents, not how they themselves parent. It is hypothesized that, when controlling for other causal variables, obsessives will (1) marry more often, (2) divorce less frequently, (3) delay reproduction longer, (4) have fewer offspring with less partners, (5) and invest more in those offspring, especially via indirect parental care, such as provisioning. This is to say at length that the reproductive behaviors of obsessives should map onto that of a slow life history strategy. Again, personality traits like conscientiousness imply pair-bonding, fidelity, and parental investment, but direct studies will provide direct data.

\section{Limitations}

Being future oriented, over-controlled, risk averse, loss averse, harm avoidant, and excessively conscientious, OCPD appears to seamlessly map onto all dimensions of the slow life history. However, there are two domains to the contrary. First, consistent with diagnostic descriptions of limited openness and flexibility (American Psychiatric Association 2000), trait studies provide evidence that four of six facets of openness to experience are inversely associated with obsessive character (Lynam and Widiger 2001). Yet, openness to experience is, for instance, part of the General Factor of Personality, an aggregate personality measure comprised of many slow life history traits (Rushton et al. 2009). Still, in some studies, openness is only marginally related to life history metrics (Dunkel and Decker 2010; Figueredo et al. 2007; Gladden et al. 2009), while in others (Rushton et al. 2008) only modest correlations (0.14) have been demonstrated. More importantly than openness, agreeableness displays a consistent and moderate correlation, which is positive for slow life history (Rushton et al. 2008; Manson 2015), and negative for obsessive personality (Widiger and Costa 1994; Furnham and Crump 2005; Samuel and Widiger 2010).

Obsessive personality, rather than being a slow life history exemplar, may be a distinct morph of the routinized and insular variety, explaining why obsessives are low on openness and agreeableness. In the context of the obsessive personality, low agreeableness, on one hand, might not have been overly impairing as per its purported evolutionary history of occupying less dense northerly regions; and low agreeableness, on the other hand, might have been co-evolved as a safeguard against exploitation of conscientious labor and hoarded resources (Hertler 2015b). Even as one can place a person or type on a life history continuum, it does not follow that the person or type should differ from those higher and lower on the continuum only in quantitative position. Instead, one must understand life history variation as a function of, or correlative to, personality variation and vice versa. Consistent with the coral reef model (Sherman et al. 2013), it then follows that variants, morphs, or types should evolve, which are nonetheless distributed along a background of quantitative change on a life history continuum. In other words, understanding life history-based personality styles to evolve via the process of adaptive diversification (Hertler 2015d) created by physical, temporal, and social environmental heterogeneity, and regulated by negative frequency dependent balancing selection (Penke 2007; Penke et al. 2007; Hertler 2015d), one would expect continuous variation yes, but also distinctiveness of variants. So it follows that any particular variant or morph will imperfectly align with comprehensive life history variables and measures. It may be that variables like the $K$ factor and covitality (Figueredo et al. 2005), and measures like the Mini$K$ (Figueredo et al. 2006) and the Arizona Life History Battery (Gladden et al. 2009) represent Platonic ideals against which actual variants and morphs deviate. In this case, however, deviation is not a matter of imperfection, but of adaptive variation on a life history theme. Encapsulating this viewpoint is Réale et al. (2010) who caution against simplification of life history theory, noting that varying selective 
pressures would promote the diversity of types. More directly, and speaking of humans, Figueredo et al. (2014b) explain that there is more specialization at the slow end of the life history spectrum resulting in the development of distinct morphs, of which OCPD seems to be one (Hertler 2014a).

\section{Diagnostic Implications}

As described, heretofore, the psychopathic personality has dominated the life history literature with resultant focus on extremes generated at the fast end of the spectrum, as illustrated by the work of Jonason and colleagues (Jonason and Webster 2010; Jonason et al. 2010; Jonason et al. 2009). Making it ever easier to pathologize $r$ strategists (Brüne et al. 2010), fast life history behaviors correlate with deviance, while also being antithetical to contemporary middle-class North American standards (Figueredo et al. 2006) and social norms of modern industrialized societies (Brumbach et al. 2009). Discordantly, however, as Del Guidice rightly concludes, OCPD is pathologized precisely because it is an extreme $K$ strategist. In consequence, obsessive personality can serve as the necessary archetypal slow life history counterpoint to the psychopathic personality, recalling the point that life history strategies can be more or less valued, but cannot be objectively ranked. Life histories are not better when slow or when fast (Wenner et al. 2013), but rather are properly understood as tradeoffs between risk and reward that have some contextually relevant outcome (Biro and Stamps 2008; Wolf and Figueredo 2011). In this way, the juxtaposition of the obsessive and psychopathic personalities within a life history perspective forces a distinction between culturally relativistic notions of pathology and objective evolutionary markers of dysfunction. Though sheltered under a century of Freudian explanation (Freud 1908/1959) and wedded to psychoanalysis through ties of ideology, history, and precedent (McCann 2009; Hertler 2014b), as this most prevalent of personality patterns (American Psychiatric Association 2013; Hertler 2015e) becomes increasingly accepted as an evolved slow life history variant, the validity of its diagnostic classification recedes. When jointly viewed within a life history framework, obsessive character and psychopathy may erode the practice and purpose of personality disorder diagnosis.

\section{References}

American Psychiatric Association. (2000). Diagnostic and statistical manual of mental disorders, 4th edition, text revision. Washington: Author.

American Psychiatric Association. (2013). Diagnostic and statistical manual of mental disorders (5th ed.). Washington: Author.
Bar-Yosef, O. \& Belfer-Cohen, A. (2000). Early human dispersals: the unexplored constraint of African diseases. Early Humans at the Gates of Europe, 79-86.

Bar-Yosef, O., \& Belfer-Cohen, A. (2001). From Africa to Eurasia - early dispersals. Quaternary International, 75, 19-28.

Belsky, J., Schlomer, G. L., \& Ellis, B. J. (2012). Beyond cumulative risk: distinguishing harshness and unpredictability as determinants of parenting and early life history strategy. Developmental Psychology, 48, 662.

Bengtson, V. L. (2001). Beyond the nuclear family: the increasing importance of multigenerational bonds. Journal of Marriage and Family, 63, 1-16.

Bering, J. M. (2004). A critical review of the "enculturation hypothesis": the effects of human rearing on great ape social cognition. Animal Cognition, 7, 201-212.

Biro, P. A., \& Stamps, J. A. (2008). Are animal personality traits linked to life-history productivity? Trends in Ecology \& Evolution, 23, 361368.

Blair, J., \& Frith, U. (2000). Neurocognitive explanations of antisocial personality disorders. Criminal Behaviour and Mental Health, 10, 66-81.

Blair, J., Mitchell, D., \& Blair, K. (2005). The psychopath: emotion and the brain. Malden: Blackwell.

Braendle, C., Heyland, A., \& Flatt, T. (2011). Integrating mechanistic and evolutionary analysis of life history variation. In T. Flatt \& A. Heyland (Eds.), Mechanisms of life history evolution: the genetics and physiology of life history traits and trade-offs (pp. 3-10). New York: Oxford University Press.

Brumbach, B. H., Figueredo, A. J., \& Ellis, B. J. (2009). Effects of harsh and unpredictable environments in adolescence on development of life history strategies. Human Nature, 20, 25-51.

Brune, M. (2008). Textbook of evolutionary psychiatry: the origins of psychopathology. New York: Oxford University Press.

Brüne, M., Ghiassi, V., \& Ribbert, H. (2010). Does borderline personality disorder reflect the pathological extreme of an adaptive reproductive strategy? Insights and hypotheses from evolutionary life-history theory. Clinical Neuropsychiatry, 7, 3-9.

Bryc, K., Durand, E. Y., Macpherson, J. M., Reich, D., \& Mountain, J. L. (2015). The genetic ancestry of African Americans, Latinos, and European Americans across the United States. The American Journal of Human Genetics, 96, 37-53.

Bufill, E., Agustí, J., \& Blesa, R. (2011). Human neoteny revisited: the case of synaptic plasticity. American Journal of Human Biology, 23, $729-739$.

Buss, D. M. (2011). Personality and the adaptive landscape: The role of individual differences in creating and solving social adaptive problems. In D. M. Buss \& P. H. Hawley (Eds.), The evolution of personality and individual differences. New York: Oxford University Press.

Campbell, B. (1972). Sexual selection and the descent of man 18711971. Chicago: Aldine Publishing Company.

Campos, L. P. (1966). Relationship between time estimation and retentive personality traits. Perceptual and Motor Skills, 23, 59-62.

Cavalli-Sforza, L., Menozzi, P., \& Piazza, A. (1994). The history and geography of human genes. Princeton: Princeton University Press.

Chapman, A. L., Lynch, T. R., Rosenthal, M. Z., Cheavens, J. S., Smoski, M. J., \& Krishnan, K. R. R. (2007). Risk aversion among depressed older adults with obsessive-compulsive personality disorder. Cognitive Therapy and Research, 31, 161-174.

Charnov, E. L. (1993). Life history invariants: some explorations of symmetry in evolutionary ecology. New York: Oxford University Press.

Chavira, D. A., Grilo, C. M., Shea, M. T., Yen, S., Gunderson, J. G., Morey, L. C., \& McGlashan, T. H. (2003). Ethnicity and four personality disorders. Comprehensive Psychiatry, 44, 483-491. 
Chisholm, J. S. (1999a). Attachment and time preference: relations between early stress and sexual behavior in a sample of American University Women. Human Nature, 10, 51-83.

Chisholm, J. S. (1999b). Death, hope, and sex: steps to an evolutionary ecology of mind and morality. New York: Cambridge University Press.

Cohen, D. (2007). Methods in cultural psychology. In S. Kitayama \& D. Cohen (Eds.), Handbook of cultural psychology (pp. 196-236). New York: Guilford.

Cohen, L. E., \& Machalek, R. (1988). A general theory of expropriative crime: an evolutionary ecological approach. American Journal of Sociology, 94, 465-501.

Colman, A. M., \& Wilson, J. C. (1997). Antisocial personality disorder: an evolutionary game theory analysis. Legal and Criminological Psychology, 2, 23-34.

Dawkins, R. (1999). The extended phenotype: the long reach of the gene. New York: Oxford University Press.

Dawkins, R. (2006). The selfish gene. Oxford: Oxford University Press.

Deary, I. J., Peter, A., Austen, E., \& Gibson, G. (1998). Personality traits and personality disorders. British Journal of Psychology, 89, 647661.

Del Giudice, M. (2014). An evolutionary life history framework for psychopathology. Psychological Inquiry, 25, 261-300.

DeYoung, C. G., \& Gray, J. R. (2009). Personality neuroscience: explaining individual differences in affect, behaviour and cognition. In P. J. Corr \& G. Matthews (Eds.), The Cambridge handbook of personality psychology (pp. 323-346). New York: Cambridge University Press.

Dumont, F. (2010). A history of personality psychology: theory, science, and research from Hellenism to the twenty-first century. New York: Cambridge University Press.

Dunkel, C. S., \& Decker, M. (2010). Convergent validity of measures of life-history strategy. Personality and Individual Differences, 48, 681-684.

Dunkel, C. S., Stolarski, M., van der Linden, D., \& Fernandes, H. B. (2014). A reanalysis of national intelligence and personality: the role of the general factor of personality. Intelligence, 47, 188-193.

Egloff, B., \& Schmukle, S. C. (2004). Gender differences in implicit and explicit anxiety measures. Personality and Individual Differences, $36,1807-1815$.

Ellis, L. (1987). Criminal behavior and $\mathrm{r} / \mathrm{k}$ selection: an extension of gene-based evolutionary theory. Deviant Behavior, 8, 149-176.

Ellis, L. (1988). Criminal behavior and $\mathrm{r} / \mathrm{K}$ selection: an extension of gene-based evolutionary theory. Personality and Individual Differences, 9, 697-708.

Ellis, B. J., Figueredo, A. J., Brumbach, B. H., \& Schlomer, G. L. (2009). Fundamental dimensions of environmental risk: the impact of harsh versus unpredictable environments on the evolution and development of life history strategies. Human Nature, 20, 204-268.

Eskedal, G. A., \& Demitri, J. M. (2006). Etiology and treatment of cluster C personality disorders. Journal of Mental Health Counseling, 28, $1-17$.

Figueredo, A. J., \& Rushton, J. P. (2009). Evidence for shared genetic dominance between the general factor of personality, mental and physical health, and life history traits. Twin Research and Human Genetics, 12, 555-563.

Figueredo, A. J., Vasquez, G., Brumbach, B. H., \& Schneider, S. M. (2004). The heritability of life history strategy: the k-factor, covitality, and personality. Biodemography and Social Biology, 51, 121-143.

Figueredo, A. J., Vasquez, G., Brumbach, B. H., Sefcek, J. A., Kirsner, B. R., \& Jacobs, W. J. (2005). The K-factor: individual differences in life history strategy. Personality and Individual Differences, 39, $1349-1360$

Figueredo, A. J., Vásquez, G., Brumbach, B. H., Schneider, S. M. R., Sefcek, J. A., Tal, I. R., et al. (2006). Consilience and life history theory: from genes to brain to reproductive strategy. Developmental Review, 26, 243-275.

Figueredo, A. J., Vásquez, G., Brumbach, B. H., \& Schneider, S. M. (2007). The K-factor, covitality, and personality. Human Nature, $18,47-73$

Figueredo, A. J., Andrzejczak, D. J., Jones, D. N., Smith-Castro, V., \& Montero, E. (2011). Reproductive strategy and ethnic conflict: slow life history as a protective factor against negative ethnocentrism in two contemporary societies. Journal of Social, Evolutionary, and Cultural Psychology, 5, 14.

Figueredo, A. J., de Baca, T. C., \& Woodley, M. A. (2013). The measurement of human life history strategy. Personality and Individual Differences, 55, 251-255.

Figueredo, A. J., de Baca, T. C., \& Black, C. (2014a). No matter where you go, there you are: the genetic foundations of temporal stability. Journal of Methods and Measurement in the Social Sciences, 5, 76106.

Figueredo, A. J., Woodley, M. A., \& Fernandes, H. B. (2014b). Life history selection and phenotypic diversification. Psychological Inquiry, 25, 325-329.

Flatt, T., \& Heyland, A. (2011). Mechanisms of life history evolution: the genetics and physiology of life history traits and trade-offs. New York: Oxford University Press.

Fossati, A., Beauchaine, T. P., Grazioli, F., Borroni, S., Carretta, I., De Vecchi, C., Cortinovis, F., Danelli, E., \& Maffei, C. (2006). Confirmatory factor analyses of DSM-IV cluster C personality disorder. Journal of Personality Disorders, 20, 186-203.

Franco, M., \& Silvertown, J. (1997). Life history variation in plants: An exploration of the fast-slow continuum hypothesis. In J. Silvertown, M. Franco, \& J. L. Harper (Eds.), Plant life histories: ecology, phylogeny, and evolution (pp. 210-227). New York: Cambridge University Press.

Frederick, S., Loewenstein, G., \& O'donoghue, T. (2002). Time discounting and time preference: a critical review. Journal of Economic Literature, 40, 351-401.

Freud, S. (1908/1959). Character and anal eroticism. In J. Strachey (Ed.), The complete psychological works of Sigmund Freud, standard Edition (Vol. 9, pp. 167-175). London: Hogarth.

Friedman, H. S., Tucker, J. S., Tomlinson-Keasey, C., Schwartz, J. E., Wingard, D. L., \& Criqui, M. H. (1993). Does childhood personality predict longevity? Journal of Personality and Social Psychology, 65, 176.

Friedman, H. S., Tucker, J. S., Schwartz, J. E., Martin, L. R., TomlinsonKeasey, C., Wingard, D. L., \& Criqui, M. H. (1995). Childhood conscientiousness and longevity: health behaviors and cause of death. Journal of Personality and Social Psychology, 68, 696.

Frost, R. O., \& Steketee, G. (Eds.). (2002). Cognitive approaches to obsessions and compulsions: theory, assessment, and treatment. Oxford: Elsevier.

Furnham, A., \& Crump, J. (2005). Personality traits, types and disorders: an examination of the relationship between three self-report measures. European Journal of Personality, 19, 167-184.

Geary, D. C. (2003). Sexual selection and human life history. Advances in Child Development and Behavior, 30, 41-101.

Gibbs Gallagher, N., South, S. C., \& Oltmanns, T. F. (2003). Attentional coping style in obsessive-compulsive personality disorder: a test of the intolerance of uncertainty hypothesis. Personality and Individual Differences, 34, 41-57.

Gladden, P. R., Sisco, M., \& Figueredo, A. J. (2008). Sexual coercion and life-history strategy. Evolution and Human Behavior, 29, 319-326.

Gladden, P. R., Figueredo, A. J., \& Jacobs, W. J. (2009). Life history strategy, psychopathic attitudes, personality, and general intelligence. Personality and Individual Differences, 46, 270-275.

Godfrey, L. R., \& Sutherland, M. R. (1996). Paradox of peramorphic paedomorphosis: heterochrony and human evolution. American Journal of Physical Anthropology, 99, 17-42. 
Grant, J. E., Mooney, M. E., \& Kushner, M. G. (2012). Prevalence, correlates, and comorbidity of DSM-IV obsessive-compulsive personality disorder: results from the National Epidemiologic Survey on Alcohol and Related Conditions. Journal of Psychiatric Research, 46, 469-475.

Griskevicius, V., Delton, A. W., Robertson, T. E., \& Tybur, J. M. (2011a). Environmental contingency in life history strategies: the influence of mortality and socioeconomic status on reproductive timing. Journal of Personality and Social Psychology, 100, 241.

Griskevicius, V., Tybur, J. M., Delton, A. W., \& Robertson, T. E. (2011b). The influence of mortality and socioeconomic status on risk and delayed rewards: a life history theory approach. Journal of Personality and Social Psychology, 100, 1015.

Gutiérrez, F., Gárriz, M., Peri, J. M., Ferraz, L., Sol, D., Navarro, J. B., Barbadilla, A., \& Valdés, M. (2013). Fitness costs and benefits of personality disorder traits. Evolution and Human Behavior, 34, 4148.

Hackman, J., \& Hruschka, D. (2013). Fast life histories, not pathogens, account for state-level variation in homicide, child maltreatment, and family ties in the US. Evolution and Human Behavior, 34, $118-124$.

Hagger-Johnson, G. E., \& Whiteman, M. C. (2007). Conscientiousness facets and health behaviors: a latent variable modeling approach. Personality and Individual Differences, 43, 1235-1245.

Haigler, E. D., \& Widiger, T. A. (2001). Experimental manipulation of NEO PI-R items. Journal of Personality Assessment, 77, 339-358.

Hall, J. G. (2003). Twinning. The Lancet, 362, 735-743.

Harcourt, A. H. (2012). Human biogeography. Berkley: University of California Press.

Hare, R. D., Forth, A. E., \& Hart, S. D. (1989). The psychopath as prototype for pathological lying and deception. In credibility assessment (pp. 25-49). Springer Netherlands

Harpending, H. C., \& Sobus, J. (1987). Sociopathy as an adaptation. Ethology and Sociobiology, 8, 63-72.

Harvey, P. H., \& Clutton-Brock, T. H. (1985). Life history variation in primates. Evolution, 39, 559-581.

Hawkes, K. (2003). Grandmothers and the evolution of human longevity. American Journal of Human Biology, 15, 380-400.

Heine, S. J., Lehman, D. R., Peng, K., \& Greenholtz, J. (2002). What's wrong with cross-cultural comparisons of subjective Likert scales?: the reference-group effect. Journal of Personality and Social Psychology, 82, 903-918.

Heine, S. J., Buchtel, E. E., \& Norenzayan, A. (2008). What do crossnational comparisons of personality traits tell us? The case of conscientiousness. Psychological Science, 19, 309-313.

Hertler, S. C. (2013). Understanding obsessive compulsive personality disorder: reviewing the specificity and sensitivity of DSM-IV-TR diagnostic criteria. Sage Open, 3, 1-10.

Hertler, S. C. (2014a). The continuum of conscientiousness: antagonistic interests among obsessive and antisocial personalities. Polish Psychological Bulletin, 45, 52-63.

Hertler, S. C. (2014b). A review and critique of obsessive compulsive personality disorder etiologies: reckoning with heritability estimates. Europe's Journal of Psychology, 10, 168-184.

Hertler, S. C. (2015a). Using urgent states to understand obsessive traits: promoting a phenomenological apperception of obsessive compulsive personality disorder. International Review of Social Sciences and Humanities., 8, 20-25.

Hertler, S. C. (2015b). The evolutionary logic of the obsessive trait complex: obsessive compulsive personality disorder as a complementary behavioral syndrome. Psychological Thought, 8, 17-34.

Hertler, S. C. (2015c). Migration load, ecological opportunity, and obsessive compulsive personality disorder etiology: obsessive character as an adaptation to seasonality. Evolutionary Psychological Science, $1,52-67$.
Hertler, S. C. (2015d). Crossing the paradigmatic divide in personality: coming to an evolutionary understanding of personality variation. Accepted and in press: Journal for Philosophy and Psychiatry.

Hertler, S. C. (2015e). Estimates \& implications of obsessive compulsive personality disorder (OCPD) prevalence: OCPD as a common disorder with a cosmopolitan distribution or rare strategy with a northerly distribution? Psychological Writings, 8, 1-12.

Hetherington, R., \& Reid, R. G. B. (2010). The climate connection: climate change and modern human evolution. New York: Cambridge University Press.

Hill, K., \& Kaplan, H. (1999). Life history traits in humans: theory and empirical studies. Annual Review of Anthropology, 28, 397-430.

Himle, J. A., Baser, R. E., Taylor, R. J., Campbell, R. D., \& Jackson, J. S. (2009). Anxiety disorders among African Americans, blacks of Caribbean descent, and non-Hispanic whites in the United States. Journal of Anxiety Disorders, 23, 578-590.

Hummelen, B., Wilberg, T., Pedersen, G., \& Karterud, S. (2008). The quality of the DSM-IV obsessive-compulsive personality disorder construct as a prototype category. Journal of Nervous and Mental Disease, 196, 446-455.

Jonason, P. K., \& Tost, J. (2010). I just cannot control myself: the dark triad and self-control. Personality and Individual Differences, 49, 611-615.

Jonason, P. K., \& Webster, G. D. (2010). The dirty dozen: a concise measure of the dark triad. Psychological Assessment, 22, 420.

Jonason, P. K., Li, N. P., Webster, G. D., \& Schmitt, D. P. (2009). The dark triad: facilitating a short-term mating strategy in men. European Journal of Personality, 23, 5-18.

Jonason, P. K., Koenig, B. L., \& Tost, J. (2010). Living a fast life: the dark triad and life history theory. Human Nature, 21, 428-442.

Jonason, P. K., Webster, G. D., Schmitt, D. P., Li, N. P., \& Crysel, L. (2012). The antihero in popular culture: life history theory and the dark triad personality traits. Review of General Psychology, 16, 192.

Jones, D. N., \& Figueredo, A. J. (2013). The core of darkness: uncovering the heart of the Dark Triad. European Journal of Personality, 27, 521-531.

Joyce, P. R., Rogers, G. R., Miller, A. L., Mulder, R. T., Luty, S. E., \& Kennedy, M. A. (2003). Polymorphisms of DRD4 and DRD3 and risk of avoidant and obsessive personality traits and disorders. Psychiatry Research, 119, 1-10.

Kamilar, J. M., \& Cooper, N. (2013). Phylogenetic signal in primate behaviour, ecology and life history. Philosophical Transactions of the Royal Society, B: Biological Sciences, 368(1618), 20120341.

Kaplan, H., \& Bock, J. (2001). Fertility theory: The embodied capital theory of human life history evolution. The international encyclopedia of the social and behavioral sciences, 5561-5568.

Kaplan, H., \& Lancaster, J. B. (2000). The evolutionary economics and psychology of the demographic transition to low fertility. In L. Cronk, N. Chagnon, \& W. Irons (Eds.), Adaptation and human behavior: an anthropological perspective (pp. 283-322). Hawthorne, New York: Aldine De Gruyter.

Kaplan, H., Hill, K., Lancaster, J., \& Hurtado, A. M. (2000). A theory of human life history evolution: diet, intelligence, and longevity. Evolutionary Anthropology Issues News and Reviews, 9, 156-185.

Kelly, E. L., \& Conley, J. J. (1987). Personality and compatibility: a prospective analysis of marital stability and marital satisfaction. Journal of Personality and Social Psychology, 52, 27-40.

Kenrick, D. T., Dantchik, A., \& MacFarlane, S. (1983). Personality, environment, and criminal behavior: An evolutionary perspective. In W. S. Laufer \& J. M. Day (Eds.), Personality theory, moral development and criminal behavior. Lexington: D.C. Heath \& Co.

Kirsner, B. R., Figueredo, A. J., \& Jacobs, W. J. (2009). Structural relations among negative affect, mate value, and mating effort. Evolutionary Psychology, 7, 374-397. 
Kofoed, L., \& MacMillan, J. (1986). Alcoholism and antisocial personality: the sociobiology of an addiction. The Journal of Nervous and Mental Disease, 174, 332-335.

Krupp, D. B., Sewall, L. A., Lalumière, M. L., Sheriff, C., \& Harris, G. T. (2012). Nepotistic patterns of violent psychopathy: evidence for adaptation? Frontiers in Psychology, 3, 1-8.

Lack, D. (1966). Population studies of birds. Oxford: Oxford University Press.

Lewinsohn, P. M., Gotlib, I. H., Lewinsohn, M., Seeley, J. R., \& Allen, N. B. (1998). Gender differences in anxiety disorders and anxiety symptoms in adolescents. Journal of Abnormal Psychology, 107, 109-117.

Low, B. S. (1988). Pathogen stress and polygamy in humans. In L. Betzig, M. B. Mulder, \& P. Turke (Eds.), Human reproductive behavior: a Darwinian perspective (pp. 115-127). New York: Cambridge University Press.

Lynam, D. R., \& Widiger, T. A. (2001). Using the five-factor model to represent the DSM-IV personality disorders: an expert consensus approach. Journal of Abnormal Psychology, 110, 401-412.

MacArthur, R. H., \& Wilson, E. O. (1967). The theory of island biogeography. Princeton: Princeton University Press.

MacDonald, K. (1997). Life history theory and human reproductive behavior. Human Nature, 8, 327-359.

MacMillan, J., \& Kofoed, L. (1984). Sociobiology and antisocial personality: an alternative perspective. Journal of Nervous and Mental Disease, 172, 701-706.

Mallinger, A. E. (2009). The myth of perfection: perfectionism in the obsessive personality. American Journal of Psychotherapy, 63, $103-131$.

Manson, J. H. (2015). Life history strategy and the HEXACO personality dimensions. Evolutionary Psychology: An International Journal of Evolutionary Approaches to Psychology and Behavior, 13(1).

Matsunaga, H., \& Seedat, S. (2007). Obsessive-compulsive spectrum disorders: cross-national and ethnic issues. CNS Spectrums, 12, 392-400.

McCann, S. J. (2005). Longevity, big five personality factors, and health behaviors: presidents from Washington to Nixon. The Journal of Psychology, 139, 273-288.

McCann, J. T. (2009). Obsessive-compulsive and negativistic personality disorders. In P. H. Blaney \& T. Millon (Eds.), Oxford textbook of psychopathology (pp. 671-691). New York: Oxford University Press.

McDonald, M. M., Donnellan, M. B., \& Navarrete, C. D. (2012). A life history approach to understanding the dark triad. Personality and Individual Differences, 52, 601-605.

Mealey, L. (1995). The sociobiology of sociopathy: an integrated evolutionary model. Behavioral and Brain Sciences, 18, 523-599.

Meehan, C. L. (2005). The effects of residential locality on parental and alloparental investment among the Aka foragers of the Central African Republic. Human Nature, 16, 58-80.

Mellars, P. (2006). Why did modern human populations disperse from Africa $\mathrm{ca}$. 60,000 years ago? A new model. Proceedings of the National Academy of Sciences, 103, 9382-9386.

Millon, T., \& Davis, R. D. (1996). Disorders of personality DSM-IV and beyond. New York: Wiley.

Mokros, A., Menner, B., Eisenbarth, H., Alpers, G. W., Lange, K. W., \& Osterheider, M. (2008). Diminished cooperativeness of psychopaths in a prisoner's dilemma game yields higher rewards. Journal of Abnormal Psychology, 117, 406.

Møller, A. P., \& Garamszegi, L. Z. (2012). Between individual variation in risk-taking behavior and its life history consequences. Behavioral Ecology, 23, 843-853.

Morey, L. C., Warner, M. B., Shea, M. T., Gunderson, J. G., Sanislow, C. A., Grilo, C., Skodol, A. E., \& McGlashan, T. H. (2003). The representation of four personality disorders by the schedule for nonadaptive and adaptive personality dimensional model of personality. Psychological Assessment, 15, 326-332.

Morris, W. F. (2009). Life history. In S. A. Levin (Ed.), The Princeton guide to ecology (pp. 72-78). Princeton: Princeton University Press.

Moss, C. J., Croze, H., \& Lee, P. C. (2011). The Amboseli elephants: a long-term perspective on a long lived mammal. Chicago: University of Chicago Press.

Muehlenbein, M. P., \& Flinn, M. V. (2011). Patterns and processes of human life history evolution. In T. Flatt \& A. Heyland (Eds.), Mechanisms of life history evolution: the genetics and physiology of life history traits and trade-offs (pp. 153-168). New York: Oxford University Press.

Nettle, D., \& Clegg, H. (2007). Personality, mating strategies, and mating intelligence. In G. Geher \& G. Miller (Eds.), Mating intelligence: sex, relationships, and the mind's reproductive system (pp. 121134). New York: Psychology Press.

Ng, T. W., \& Feldman, D. C. (2010). Human capital and objective indicators of career success: the mediating effects of cognitive ability and conscientiousness. Journal of Occupational and Organizational Psychology, 83, 207-235.

O’Connor, D. B., Conner, M., Jones, F., McMillan, B., \& Ferguson, E. (2009). Exploring the benefits of conscientiousness: an investigation of the role of daily stressors and health behaviors. Annals of Behavioral Medicine, 37, 184-196.

Okello, J. B. A., Wittemyer, G., Rasmussen, H. B., Arctander, P., Nyakaana, S., Douglas-Hamilton, I., \& Siegismund, H. R. (2008). Effective population size dynamics reveal impacts of historic climatic events and recent anthropogenic pressure in African elephants. Molecular Ecology, 17, 3788-3799.

Olderbak, S. G., \& Figueredo, A. J. (2010). Life history strategy as a longitudinal predictor of relationship satisfaction and dissolution. Personality and Individual Differences, 49, 234-239.

Olderbak, S., Gladden, P., Wolf, P. S. A., \& Figueredo, A. J. (2014). Comparison of life history strategy measures. Personality and Individual Differences, 58, 82-88.

Paulhus, D. L., \& Williams, K. M. (2002). The dark triad of personality: narcissism, Machiavellianism, and psychopathy. Journal of Research in Personality, 36, 556-563.

Peng, K., Nisbett, R. E., \& Wong, N. Y. C. (1997). Validity problems comparing values across cultures and possible solutions. Psychological Methods, 2, 329-344.

Penke, L. (2007). Approaches to an evolutionary personality psychology (Doctoral dissertation, Humboldt-Universität zu Berlin, Mathematisch-Naturwissenschaftliche Fakultät II).

Penke, L., Denissen, J. A., \& Miller, G. F. (2007). The evolutionary genetics of personality. European Journal of Personality, 21, 549587.

Perin, N. (2009). Dispersal. In S. A. Levin (Ed.), The Princeton guide to ecology (pp. 45-50). Princeton: Princeton University Press.

Petanjek, Z., Judaš, M., Šimić, G., Rašin, M. R., Uylings, H. B., Rakic, P., \& Kostović, I. (2011). Extraordinary neoteny of synaptic spines in the human prefrontal cortex. Proceedings of the National Academy of Sciences, 108, 13281-13286.

Petry, N. M. (2002). Discounting of delayed rewards in substance abusers: relationship to antisocial personality disorder. Psychopharmacology, 162, 425-432.

Pettit, T. F. (1969). Anality and time. Journal of Consulting and Clinical Psychology, 33, 170-174.

Phillips, B. L., Kelehear, C., Pizzatto, L., Brown, G. P., Barton, D., \& Shine, R. (2010). Parasites and pathogens lag behind their host during periods of host range advance. Ecology, 91, 872-881.

Pinto, A., Steinglass, J. E., Greene, A. L., Weber, E. U., \& Simpson, H. B. (2014). Capacity to delay reward differentiates obsessivecompulsive disorder and obsessive-compulsive personality disorder. Biological Psychiatry, 75, 653-659. 
Pollak, J. M. (1979). Obsessive-compulsive personality: a review. Psychological Bulletin, 86, 225-241.

Pollak, J. M. (1987). Obsessive-compulsive personality: theoretical and clinical perspectives and recent research findings. Journal of Personality Disorders, 1, 248-262.

Portnoy, J., Raine, A., Chen, F. R., Pardini, D., Loeber, R., \& Jennings, J. R. (2014). Heart rate and antisocial behavior: the mediating role of impulsive sensation seeking. Criminology, 52, 292-311.

Promislow, D. E., \& Harvey, P. H. (1990). Living fast and dying young: a comparative analysis of life-history variation among mammals. Journal of Zoology, 220, 417-437.

Quinlan, R. J., \& Quinlan, M. B. (2008). Human lactation, pair-bonds, and alloparents. Human Nature, 19, 87-102.

Quinsey, V. L. (2002). Evolutionary theory and criminal behaviour. Legal and Criminological Psychology, 7, 1-13.

Rae, J. (1834/1905). The sociological theory of capital: being a complete reprint of the new principles of political economy, 1834. Macmillan.

Réale, D., Gallant, B. Y., Leblanc, M., \& Festa-Bianchet, M. (2000). Consistency of temperament in bighorn ewes and correlates with behaviour and life history. Animal Behaviour, 60, 589-597.

Réale, D., Garant, D., Humphries, M. M., Bergeron, P., Careau, V., \& Montiglio, P. O. (2010). Personality and the emergence of the paceof-life syndrome concept at the population level. Philosophical Transactions of the Royal Society, B: Biological Sciences, 365, 4051-4063.

Reich, D. E., \& Goldstein, D. B. (1998). Genetic evidence for a Paleolithic human population expansion in Africa. Proceedings of the National Academy of Sciences of the United States of America, 95, 8119-8123.

Roberts, B. W., Chernyshenko, O. S., Stark, S., \& Goldberg, L. R. (2005). The structure of conscientiousness: an empirical investigation based on seven major personality questionnaires. Personnel Psychology, $58,103-139$.

Rosenwald, G. C. (1972). Effectiveness of defenses against anal impulse arousal. Journal of Consulting and Clinical Psychology, 39, 292 298.

Rushton, J. P. (1985). Differential K theory: the sociobiology of individual and group differences. Personality and Individual Differences, 6 , $441-452$.

Rushton, J. P. (1987). An evolutionary theory of health, longevity, and personality: sociobiology and $\mathrm{r} / \mathrm{K}$ reproductive strategies. Psychological Reports, 60, 539-549.

Rushton, J. P. (1990). Sir Francis Galton, epigenetic rules, genetic similarity theory, and human life history analysis. Journal of Personality, $58,117-140$.

Rushton, J. P. (1995). Race, evolution, and behavior: a life history perspective. New Brunswick: Transaction Publishers.

Rushton, J. P. (2000). Race, evolution, and behavior: a life history perspective (3rd ed.). Port Huron: Charles Darwin Research Institute.

Rushton, J. P. (2004). Placing intelligence into an evolutionary framework or how $\mathrm{g}$ fits into the r-K matrix of life history traits including longevity. Intelligence, 32, 321-328.

Rushton, J. P., Bons, T. A., \& Hur, Y. M. (2008). The genetics and evolution of the general factor of personality. Journal of Research in Personality, 42, 1173-1185.

Rushton, J. P., Bons, T. A., Ando, J., Hur, Y. M., Irwing, P., Vernon, P. A., \& Barbaranelli, C. (2009). A general factor of personality from multitrait-multimethod data and cross-national twins. Twin Research and Human Genetics, 12, 356-365.

Salzman, L. (1985). Treatment of the obsessive personality. New York: Jason Aronson.

Samuel, D. B., \& Widiger, T. A. (2008). A meta-analytic review of the relationship between the five-factor model and the DSM-IV-TR personality disorders: a facet level analysis. Clinical Psychology Review, 28, 1326-1342.
Samuel, D. B., \& Widiger, T. A. (2010). A comparison of obsessivecompulsive personality disorder scales. Journal of Personality Assessment, 92, 232-240.

Samuel, D. B., \& Widiger, T. A. (2011). Conscientiousness and obsessive-compulsive personality disorder. Personality Disorders: Theory, Research, and Treatment, 2, 161-174.

Schechter, D. E., \& Francis, C. M. (2010). A life history approach to understanding youth time preference: mechanisms of environmental risk and uncertainty and attitudes toward risk behavior and education. Human Nature, 21, 140-164.

Schluter, D. (2000). The ecology of adaptive radiation: Oxford series in ecology and evolution. New York: Oxford University Press.

Schmit, M. J., Ryan, A. M., Stierwalt, S. L., \& Powell, A. B. (1995). Frame-of-reference effects on personality scale scores and criterion related validity. Journal of Applied Psychology, 80, 607.

Schneidera, F., Habela, U., Kesslera, C., Posseb, S., Grodd, W., \& MüllerGärtnerd, H. (2000). Functional imaging of conditioned aversive emotional responses in antisocial personality disorder. Neuropsychobiology, 42, 192-201.

Seto, M. C., Khattar, N. A., Lalumière, M. L., \& Quinsey, V. L. (1997). Deception and sexual strategy in psychopathy. Personality and Individual Differences, 22, 301-307.

Shackelford, T. K., \& Buss, D. M. (1997). Spousal esteem. Journal of Family Psychology, 11, 478.

Shapiro, D. (1999). Neurotic styles. New York: Basic Books.

Shea, J. J. (2007). Behavioral differences between middle and upper paleolithic Homo sapiens in the East Mediterranean Levant: the roles of intraspecific competition and dispersal from Africa. Journal of Anthropological Research, 63, 449-488.

Sher, K. J., \& Trull, T. J. (1994). Personality and disinhibitory psychopathology: alcoholism and antisocial personality disorder. Journal of Abnormal Psychology, 3, 92-102.

Sherman, R. A., Figueredo, A. J., \& Funder, D. C. (2013). The behavioral correlates of overall and distinctive life history strategy. Journal of Personality and Social Psychology, 105, 873-888.

Skinner, J. D., \& Chimimba, C. T. (Eds.). (2005). The mammals of the southern African sub-region. Cambridge: Cambridge University Press.

Slutske, W. S., Eisen, S., Xian, H., True, W. R., Lyons, M. J., Goldberg, J., \& Tsuang, M. (2001). A twin study of the association between pathological gambling and antisocial personality disorder. Journal of Abnormal Psychology, 110, 297-308.

Sperry, L. (2003). Handbook of diagnosis and treatment of DSM-IV-TR personality disorders (2nd ed.). New York: Brunner-Routledge.

Spinhoven, P., Bamelis, L., Molendijk, M., Haringsma, R., \& Arntz, A. (2009). Reduced specificity of autobiographical memory in cluster $\mathrm{C}$ personality disorders and the role of depression, worry and experiential avoidance. Journal of Abnormal Psychology, 118, 520-530.

Stearns, S. C. (1983). The influence of size and phylogeny on patterns of covariation among life-history traits in the mammals. Oikos, 41, 173-187.

Stearns, S. C. (1992). The evolution of life histories. New York: Oxford University Press.

Steenkamp, M. M., Suvak, M. K., Dickstein, B. D., Shea, M. T., \& Litz, B. T. (2015). Emotional functioning in obsessive-compulsive personality disorder: comparison to borderline personality disorder and healthy controls. Journal of Personality Disorders, 6, 1-15.

Swets, M., Dekker, J., van Emmerik-van Oortmerssen, K., Smid, G. E., Smit, F., de Haan, L., \& Schoevers, R. A. (2014). The obsessive compulsive spectrum in schizophrenia, a meta-analysis and metaregression exploring prevalence rates. Schizophrenia Research, 152, $458-468$.

Ullrich, S., Farrington, D. P., \& Coid, J. W. (2007). Dimensions of DSMIV personality disorders and life-success. Journal of Personality Disorders, 21, 657-663. 
van de Vijver, F., \& Leung, K. (2001). Personality in cultural context: methodological issues. Journal of Personality, 69, 1007-1031.

van Schaik, C. P., \& Isler, K. (2012). Life history evolution in primates. In J. C. Mitani, J. Call, P. M. Kappeler, R. A. Palombit, \& J. B. Silk (Eds.), The evolution of primate societies (pp. 220-244). Chicago: Chicago University Press.

Vesga-López, O., Schneier, F. R., Wang, S., Heimberg, R. G., Liu, S. M., Hasin, D. S., \& Blanco, C. (2008). Gender differences in generalized anxiety disorder: results from the National Epidemiologic Survey on Alcohol and Related Conditions (NESARC). The Journal of Clinical Psychiatry, 69, 1606.

Villemarette-Pittman, N. R., Stanford, M. S., Greve, K. W., Houston, R. J., \& Mathias, C. W. (2004). Obsessive-compulsive personality disorder and behavioral disinhibition. The Journal of Psychology, 138, $5-22$.

Vindenes, Y., Sæther, B. E., \& Engen, S. (2012). Effects of demographic structure on key properties of stochastic density-independent population dynamics. Theoretical Population Biology, 82, 253-263.

Völlm, B., Richardson, P., Stirling, J., Elliott, J., Dolan, M., Chaudhry, I., Del Ben, C., Mckie, S., Anderson, I., \& Deakin, B. (2004). Neurobiological substrates of antisocial and borderline personality disorder: preliminary results of a functional fMRI study. Criminal Behaviour and Mental Health, 14, 39-54.

Walker, R. S., \& Hamilton, M. J. (2008). Life-history consequences of density dependence and the evolution of human body size. Current Anthropology, 49, 115-122.

Walsh, A., \& Wu, H. H. (2008). Differentiating antisocial personality disorder, psychopathy, and sociopathy: evolutionary, genetic, neurological, and sociological considerations. Criminal Justice Studies, $21,135-152$.

Wang, X. (2006). Antisocial personality disorder and gambling: comments on Pietrzak \& Petry (2005). Addiction, 101, 748-749.

Warner, M. B., Morey, L. C., Finch, J. F., Gunderson, J. G., Skodol, A. E., Sanislow, C. A., \& Grilo, C. M. (2004). The longitudinal relationship of personality traits and disorders. Journal of Abnormal Psychology, 113, 217-227.
Weizmann, F., Wiener, N. I., Wiesenthal, D. L., \& Ziegler, M. (1990). Differential K theory and racial hierarchies. Canadian Psychology/ Psychologie Canadienne, 31, 1.

Wenner, C. J., Bianchi, J., Figueredo, A. J., Rushton, P., \& Jacobs, W. J. (2013). Life history theory and social deviance: the mediating role of executive function. Intelligence, 41, 102-113.

Wertheim, H. F. L., Horby, P., \& Woodall, J. P. (2012). Atlas of human infectious diseases. Hoboken: Wiley-Blackwell.

Widiger, T. A., \& Costa, P. T. (1994). Personality and personality disorders. Journal of Abnormal Psychology, 103, 78-91.

Widiger, T. A., Trull, T. J., Clarkin, J. F., Sanderson, C., \& Costa, P. T. (2002). A description of the DSM-IV personality disorders with the five-factor model of personality. In P. T. Costa \& T. A. Widiger (Eds.), Personality disorders and the five factor model of personality (pp. 89-99). Washington: American Psychological Association.

Wilson, E. O. (1975/2000). Sociobiology. Harvard University Press.

Wilson, D. S., Near, D., \& Miller, R. R. (1996). Machiavellianism: a synthesis of the evolutionary and psychological literatures. Psychological Bulletin, 119, 285-299.

Wolf, P. S., \& Figueredo, A. J. (2011). Fecundity, offspring longevity, and assortative mating: parametric tradeoffs in sexual and life history strategy. Biodemography and Social Biology, 57, 171-183.

Wolf, M., Van Doorn, G. S., Leimar, O., \& Weissing, F. J. (2007). Lifehistory trade-offs favour the evolution of animal personalities. Nature, 447, 581-584.

Woodward, A. T., Taylor, R. J., Bullard, K. M., Aranda, M. P., Lincoln, K. D., \& Chatters, L. M. (2012). Prevalence of lifetime DSM-IV affective disorders among older African Americans, Black Caribbeans, Latinos, Asians and Non-Hispanic White people. International Journal of Geriatric Psychiatry, 27, 816-827.

Yoder, J. B., Clancey, E., Des Roches, S., Eastman, J. M., Gentry, L., et al. (2010). Ecological opportunity and the origin of adaptive radiations. Journal of Evolutionary Biology, 23, 1581-1596.

Zeier, J. D., Baskin-Sommers, A. R., Hiatt Racer, K. D., \& Newman, J. P. (2012). Cognitive control deficits associated with antisocial personality disorder and psychopathy. Personality Disorders: Theory, Research, and Treatment, 3, 283-293. 